\title{
Chemical Control of Pileamicrophylla in Cattleya Seedlings (Cattleyatenebrosa $\times$ Cattleyaleopoldy) ${ }^{1}$
}

\author{
Controle Químico de Pilea microphylla em Mudas de Catleia \\ (Cattleya tenebrosa $x$ Cattleya leopoldy)
}

\begin{abstract}
BATTISTUS, A.G. ${ }^{2}$, KLEIN, J. ${ }^{2}$, COSTA, N.V. ${ }^{2}$, GUIMARÃES, V.F. ${ }^{2}$, and HOFFMANN, V. ${ }^{2}$
ABSTRACT - Species of the orchidaceae family are grown for marketing flowers and among them the genus Cattleya stands out. However, due to its slow growth, the substrate is subjected to weed infestation. Therefore, this study aims to evaluate the selectivity and efficiency of herbicides in controlling Pilea microphylla in Cattleya orchid seedlings (Cattleya tenebrosa $\mathrm{x}$ Cattleya leopoldy). We used a completely randomized design with four replications. The evaluated herbicides were oxyfluorfen $\left(0,120,240\right.$ and $\left.480 \mathrm{~g} \mathrm{ha}^{-1}\right)$, flumioxazin $(0,12.5,25$ and $\left.40 \mathrm{~g} \mathrm{ha}^{-1}\right)$, nicosulfuron $\left(0,20,40\right.$ and $\left.80 \mathrm{~g} \mathrm{ha}^{-1}\right)$ mesotrione $\left(0,96,144\right.$ and $\left.192 \mathrm{~g} \mathrm{ha}^{-1}\right)$, clethodim (0, 60, 84 and $\left.108 \mathrm{~g} \mathrm{ha}^{-1}\right)$ and metsulfuron-methyl $\left(0,1.2,1.8\right.$ and $\left.2.4 \mathrm{~g} \mathrm{ha}^{-1}\right)$. At post-emergence applying time, the Cattleya plants had three bulb sand were $10 \mathrm{~cm}$ tall, while $P$. microphylla, where $5 \mathrm{~cm}$ tall. Nicosulfuron, mesotrione and clethodim herbicides did not control $P$. microphylla, while oxyfluorfen and flumioxazin showed over $90 \%$ efficiency level sin controlling $P$. microphyllafrom 14 days after application (DAA). As to metsulfuron-methyl, it showed efficiency superior to $90 \%$ from the control dose of $1.8 \mathrm{~g} \mathrm{ha}^{-1}$ at $28 \mathrm{DAA}$. All herbicides were selective plants of Cattleya, however, only oxyfluorfen, flumioxazin and metsulfuronmethyl were effective in controlling P. microphylla.
\end{abstract}

Keywords: weed, herbicide, floriculture, selectivity.

RESUMO - Espécies da família Orchidaceae são cultivadas para comercialização de flores; entre elas, destaca-se o gênero Cattleya. Entretanto, devido ao seu crescimento lento, o substrato fica sujeito à infestação de plantas daninhas. Portanto, objetivou-se neste estudo avaliar a seletividade e eficiência de herbicidas no controle de Pilea microphylla em mudas de orquidea Catleia (Cattleya tenebrosa $\boldsymbol{x}$ Cattleya leopoldy). Foi utilizado delineamento inteiramente casualizado com quatro repetições. Os herbicidas avaliados foram: oxyfluorfen (0, 120, 240 e $480 \mathrm{~g} \mathrm{ha}$ ), flumioxazin

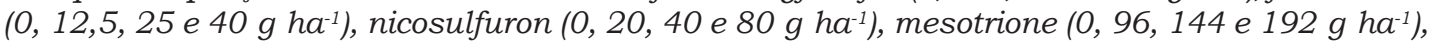

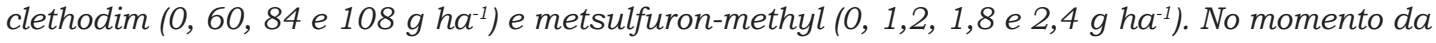
aplicação em pós-emergência, as plantas de Catleia apresentavam três bulbos e altura de $10 \mathrm{~cm}$, e $\boldsymbol{P}$. microphylla, $5 \mathrm{~cm}$ de altura. Os herbicidas nicosulfuron, mesotrione e clethodim não controlaram $\boldsymbol{P}$. microphylla, enquanto as doses do oxyfluorfen e do flumioxazin apresentaram eficiência no controle de $\boldsymbol{P}$. microphylla superior a 90\% a partir dos 14 dias após a aplicação (DAA). Já o metsulfuron-methyl mostrou eficiência superior a 90\% de controle a partir da dose de 1,8 $\mathrm{g} \mathrm{ha}$ aos 28 DAA. Todos os herbicidas foram considerados seletivos a Catleia; contudo, apenas oxyfluorfen, flumioxazin e metsulfuron-methyl foram eficientes no controle de $\boldsymbol{P}$. microphylla.

Palavras-chave: planta daninha, herbicida, floricultura, seletividade.

Recebido para publicação em 28.1.2014 e aprovado em 2.8.2014.

Universidade Estadual do Oeste do Paraná, Rondon-PR, Brasil; <neumarciovc@hotmail.com>.

Planta Daninha, Viçosa-MG, v. 32, n. 4, p. 801-807, 2014 


\section{INTRODUCTION}

Amongall ornamental plants marketed, the ones from the orchid family deserve prominent role, due to its high acceptance and exuberance of its flowers (Freitas et al., 2007a), as well as showing great adaptability to various environments (Paula \& Silva, 2006).

For commercial cultivation, using quality substrate, which supports the development of these flowering, becomes extremely important (Assis et al., 2010). However, orchids growth happens slowly (Suzuki et al., 2010), exposing the substrate for long periods to colonization by weeds such as Pilea microphylla (brilhantina), which affects seedlings development, increasing the cost of production and reducing their commercial value (Freitas et al., 2007b).

At orchard sin the western Parana, producers emphasize that $P$. microphylla occur sin high levels of infestation in nurseries and tha tits manual control is expensive due to the need for constant grubbing and the reduction of the aesthetic pot beauty (personal communication).

P. microphylla presents fast development in shaded and high humidity conditions, being opportunistic and commonly observed along the potted ornamental plants (Rodrigues et al., 2007). The ornamentals potted and bags Pilea microphylla (brilhantina) control is usually done by manual hoeing; regrowth could occur if the plant is not totally eliminated, since it easily emits new growing in the collecting region. Also, the high production of seeds that are easily transported by wind and handling promotes rapid reinfestation (Freitas et al, 2007b;. Lorenzi \& Souza, 2008).

Thus, chemical control stands out as an alternative for the management of $P$. microphylla incommercial orchid houses, since there would be considerable savings from the use of labor and operating time point of view (Maciel et al., 2005). However, in literature, there are few works that present studies on the chemical control of P. microphylla (Freitas et al., 2007a, b).

Therefore, it is necessary to get information on new chemicals for weed management and rotation of active ingredients to aid in the control of $P$. microphylla without harming the orchids development.

Thus, the objective of this study was to evaluate the efficacy of herbicides for controlling P. microphylla in Cattleya orchids seedlings (Cattleya tenebrosa x Cattleya leopoldy).

\section{MATERIALS AND METHODS}

This experiment was conducted under shading cloth, $75 \%$ shading, at the Experimental Station of Horticulture and Biological Control Professor Mário César Lopes

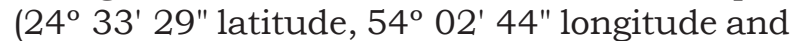
altitude of $411 \mathrm{~m}$ ) belonging to Universidade Estadual do Oeste do Paraná - Unioeste, campus Marechal Cândido Rondon, PR, in the March-May 2013 period.

The experimental design used was completely randomized with four replications. The experiment was made up of six chemical compounds, studied in 24 treatments with four concentrations for each product: oxyfluorfen $\left(0,120,240\right.$ and $\left.480 \mathrm{~g} \mathrm{ha}^{-1}\right)$, flumioxazin $(0$, $12.5,25$ and $\left.40 \mathrm{~g} \mathrm{ha}^{-1}\right)$, nicosulfuron $(0 ; 20 ; 40$ and $\left.80 \mathrm{~g} \mathrm{ha}^{-1}\right)$, mesotrione $(0,96,144$ and $\left.192 \mathrm{~g} \mathrm{ha}^{-1}\right)$, clethodim $\left(0,60,84\right.$ and $\left.108 \mathrm{~g} \mathrm{ha}^{-1}\right)$ and metsulfuron-methyl $(0,1.2,1.8$ and $\left.2.4 \mathrm{~g} \mathrm{ha}^{-1}\right)$.

Each plot consisted of a pot filled with $0.4 \mathrm{~kg}$ of substrate infested with $P$. microphylla, containing a seedling of Cattleya hybrid orchid (Cattleya tenebrosa $\mathrm{x}$ Cattleya leopoldy) with three bulbs and a $10 \mathrm{~cm}$ tall. Pilea microphylla (brilhantina) was five centimeter stall. Cattleya seedlings were obtained from Esplendor Orchid House, in Marechal Cândido Rondon-PR.

After every five days, orchids were sprayed using a hand spray with $20 \mathrm{~mL}$ per plant of nutritive solution containing 8.00, 20.00, $12.00,1.00,0.30,3.00,0.07,0.02,0.04$ and $0.03 \%$ of $\mathrm{N}, \mathrm{P}, \mathrm{K}, \mathrm{Ca}, \mathrm{Mg}, \mathrm{S}, \mathrm{Fe}, \mathrm{Mn}, \mathrm{B}$ and $\mathrm{Zn}$, respectively, as recommended by theproducer (Esplendor Orchid House).

The product spraying was made in the total area of the pot using the help of knapsack sprayer at constant pressure by $\mathrm{CO}_{2}$, equipped with four Magno 11002 ADGA tips, spaced $0.5 \mathrm{~m}$, at pressure of $400 \mathrm{kPa}$, providing a spray volume of $200 \mathrm{~L} \mathrm{ha}^{-1}$. At application 
temperature was $24{ }^{\circ} \mathrm{C}$, and relative humidity, $67 \%$. Wind speed was $4 \mathrm{~km} \mathrm{~h}^{-1}$.

The control evaluation of $P$. microphylla and phytotoxicity of Cattleya plants were made at $4,7,14,21,28,35,42$ and 49 days after application (DAA). Theywere made by means of the percentage scale visual notes, where 0 (zero) corresponds to no injury demonstrated by the plant and one hundred (100) to the death of plants, as proposed by SBCPD (1995).

The data were adjusted at multiple regression models, with surface charts being built. Equations were chosen based on significant models with biological logicand high $\mathrm{R}^{2}$.

\section{RESULTS AND DISCUSSION}

Figure 1 shows the control data of P. microphylla in Cattleya seedlings after herbicide application. It was found that oxyfluorfen and flumioxazin rapidly showed efficient control of $P$. microphylla exceeding $90 \%$ from 14 DAA at all tested doses. As for metsulfuron-methyl, satisfactory control has been obtained from 28 DAAat upper $1.8 \mathrm{~g} \mathrm{ha}^{-1}$ doses.

After seven weeks (49 days) of the experiment, oxyfluorfen, flumioxazin and metsulfuron-methyl herbicides achieved satisfactory efficacy, exercising full control over the weed.

It was also observed that oxyfluorfen and flumioxazin inhibited germination and issuance of new growth of $P$. microphylla throughout this study period, while other molecules did not provide this effect. Both herbicides are either absorbed by the roots and the leaves, and have great persistence in soil (Jursik et al., 2011; Jung, 2011).

Freitas et al. (2007b) verified efficient control of $P$. microphylla, above $90 \%$ at 30 DAA, from doses of 300,320 and $340 \mathrm{~kg} \mathrm{ha}^{-1}$ of oxyfluorfen, for Zantedeschia aethiopica (calla lily), Strelitzia reginae (Strelitzia) and Archontophoenix cunninghamiana (Australian palm) ornamental plants, respectively. Phytointoxication symptoms considered mild appearin ornamental plant, being more evident in plants of $A$. cunninghamiana.
Thus, the authors recommend directed applicationas the most suitable for sensitive leaf and/or possessing impressive leaf area, promoting the"umbrella effect", application species.

In another study, Freitas et al. (2007a) found that oxyfluorfen was selective to Epidendrum ibaguensis and Dendrobium sp. orchids and provided efficient control of P. microphylla, above $90 \%$ at $30 \mathrm{DAA}$, for more than $62.4 \mathrm{~g} \mathrm{ha}^{-1}$ doses.

Nicosulfuron, mesotrione and the clethodim did not provide satisfactory control of P. microphylla. However, applications of clethodim apparently stimulated the development, while mesotrione induced P. microphylla flowering (not evaluated data).

Regarding phytotoxicityin Cattleya seedlings after herbicide application (Figures 2 and 3), it was found that all molecules shown to be selective to plants.

According Macielet al. (2005), metsulfuronmethyl (2.4 $\left.\mathrm{g} \mathrm{ha}^{-1}\right)$ and clethodim (120 $\left.\mathrm{g} \mathrm{ha}^{-1}\right)$ showed wide selectivity to Euphorbia splendens (christ plant), causing no reduction in visual quality and mainly in inflorescences development. As for nicosulfuron $\left(60 \mathrm{~g} \mathrm{ha}^{-1}\right)$, these authors recommended the application in the E. splendens vegetative period, to prevent damage to inflorescences.

Regading Pivetta et al. (2008), it was reported that the application of oxyfluorfen was not selective concerning Salvia splendens (salvia) plants, while the herbicide at a dose of $480 \mathrm{~g} \mathrm{ha}^{-1}$, with to $4 \mathrm{tha}^{-1}$ of rice straw, provided satisfactory control of weed plants without harming $S$. splendens plants.

In general, the results obtained in this study demonstrated that the use of herbicides can reduce high levels of infestation of $P$. microphylla in orchids seedling nurseries in a more practical and faster way than the manual control mode, be sides ensuring the beauty aesthetics of the pots and its commercial value.

Thus, it can be concluded that the evaluated herbicides were considered selective to Cattleya seedling (Cattleya tenebrosa $\mathrm{x}$ Cattleya leopoldy), while only oxyfluorfen, flumioxazin and metsulfuron-methyl herbicides were effective in controlling $P$. microphylla. 

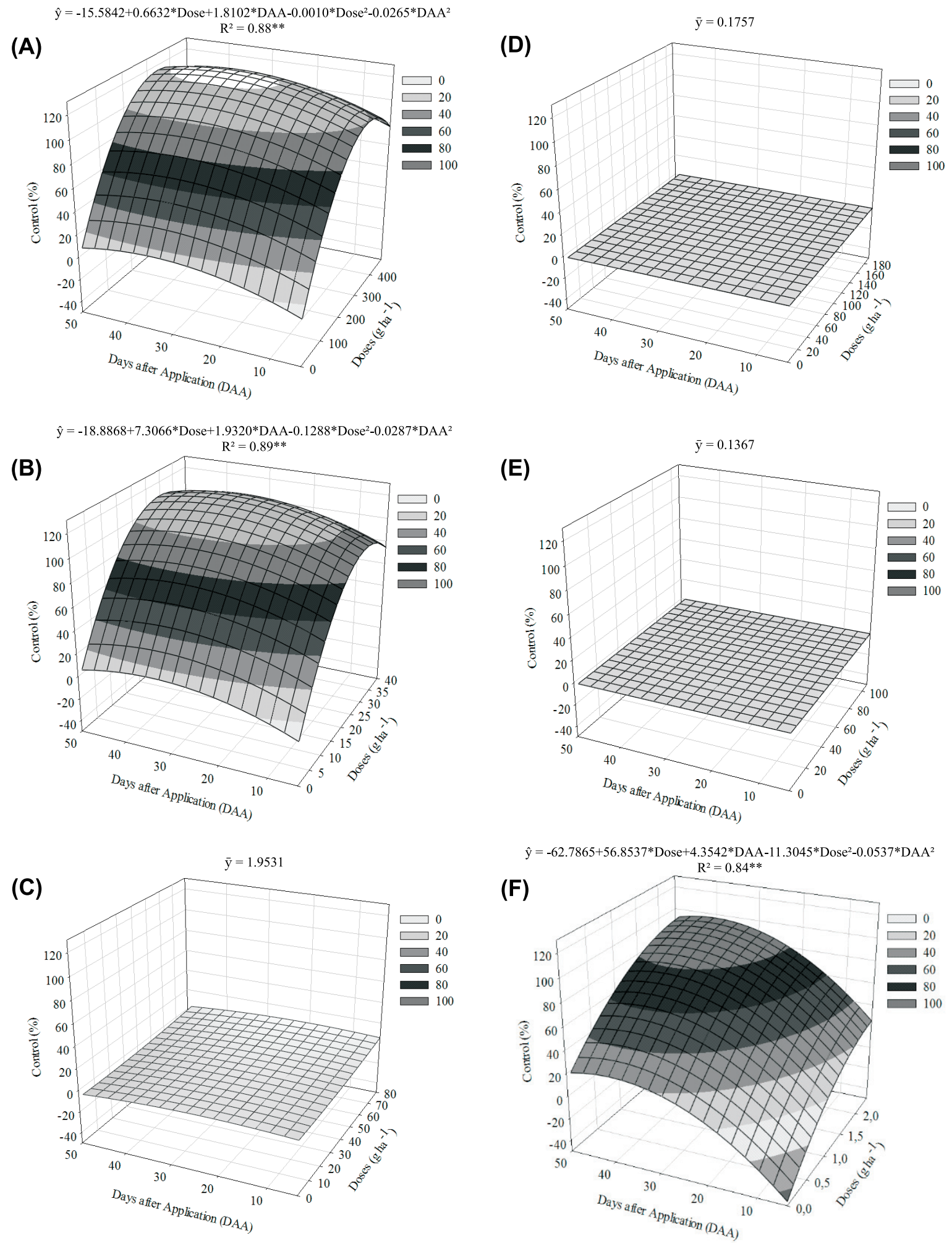

\footnotetext{
** Significant at $1 \%$ probability by $\mathrm{F}$ test.
}

Figure 1 - Control of $P$. microphylla in Cattleya seedlings after herbicide application. (A) oxyfluorfen, (B) flumioxazin (C) nicosulfurom, (D) mesotrione, (E) clethodim and (F) metsulfuron-methyl. 

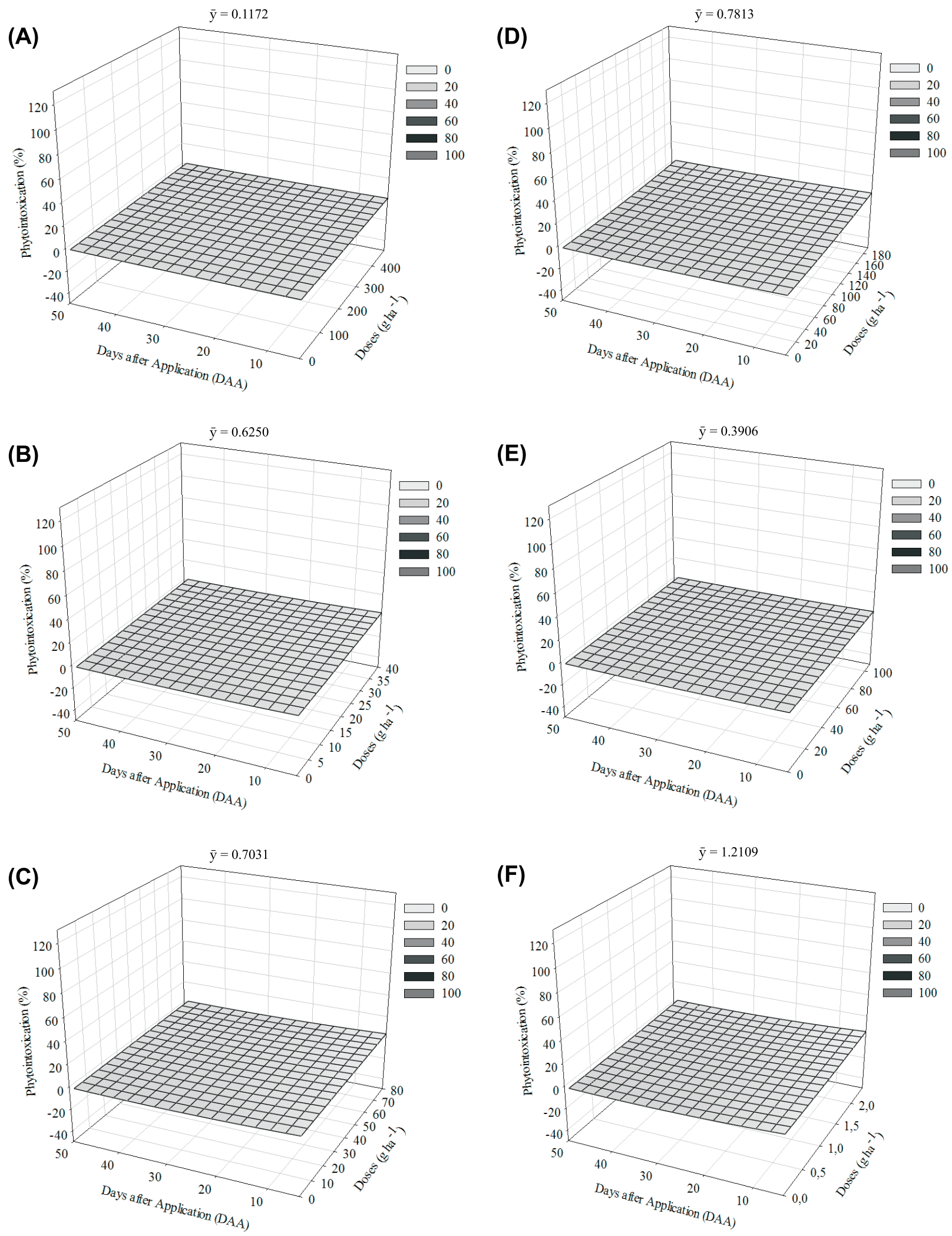

Figure 2- phytotoxicity in Cattleya seedlings after herbicide application. (A) oxyfluorfen, (B) flumioxazin (C) nicosulfurom, (D) mesotrione, (E) clethodim and (F) metsulfuron-methyl. 

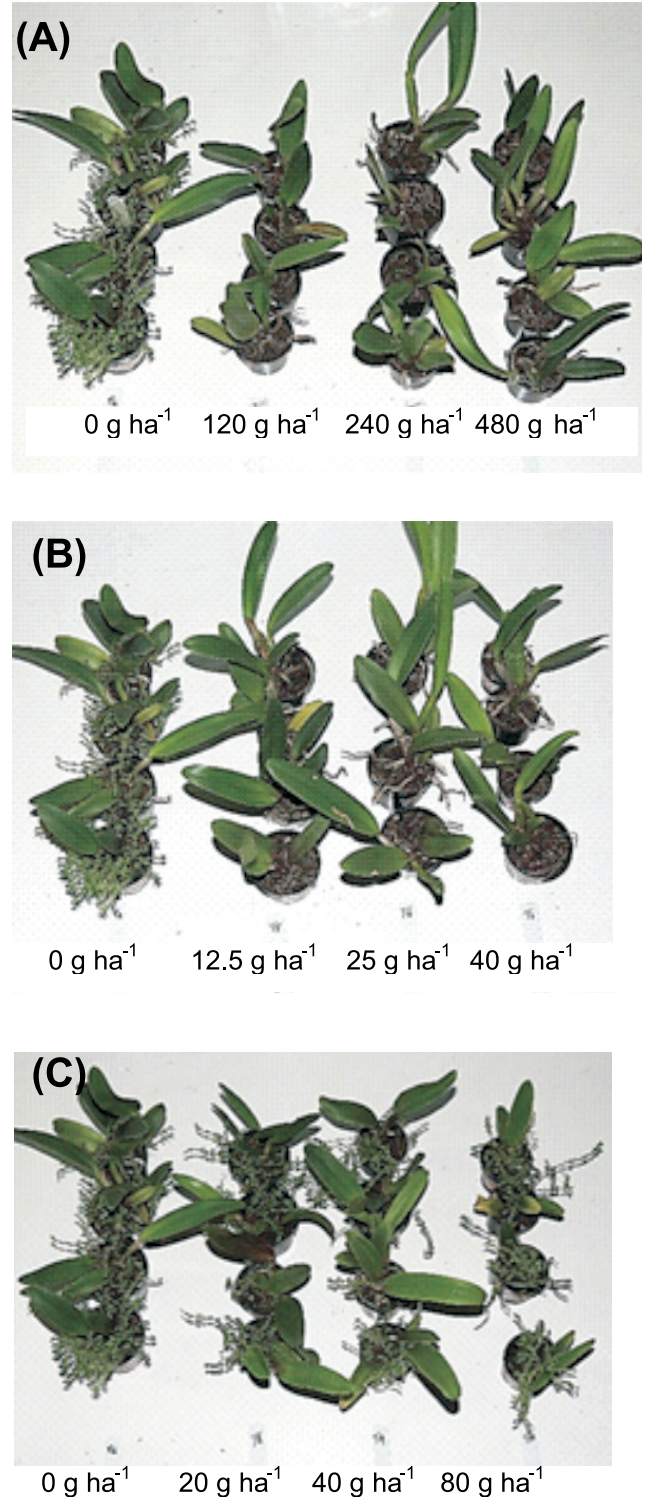

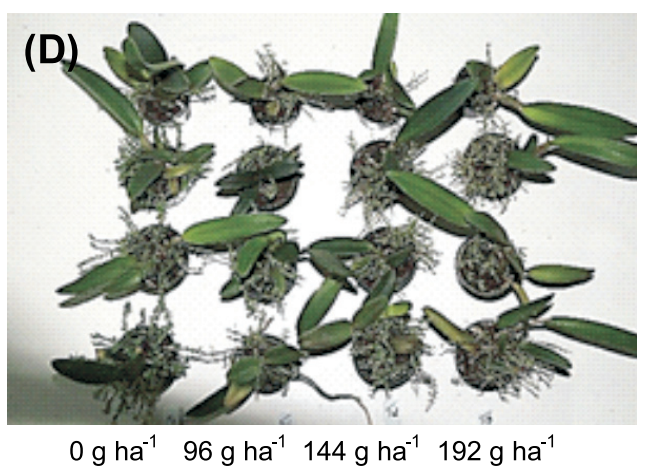

(E)
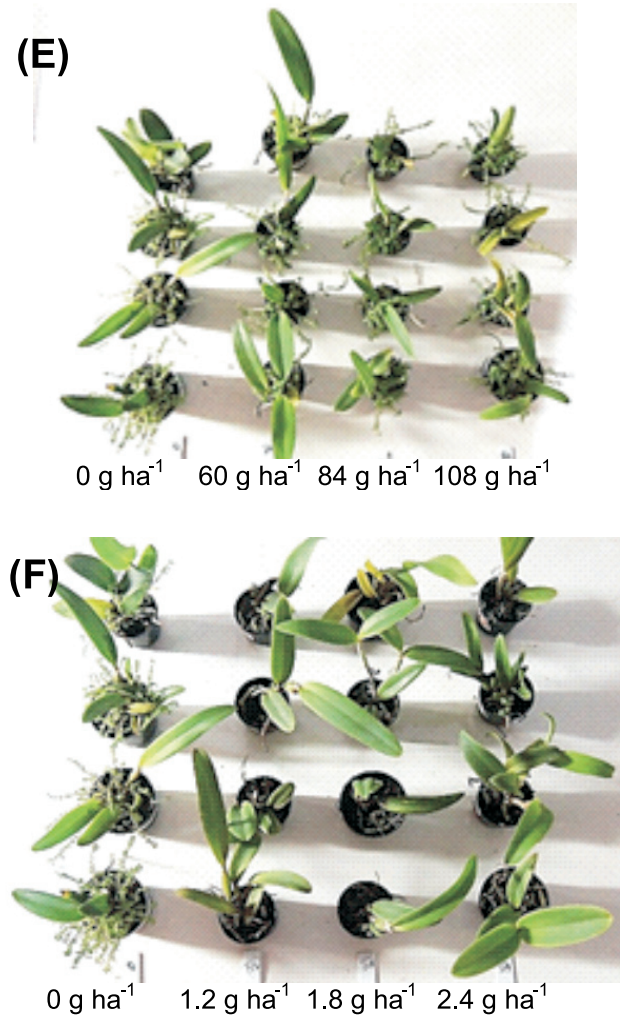

Figure 3 - Cattleya seedlings (Cattleya tenebrosa x Cattleya leopoldy) appearance at 49 days after herbicide application. (A) oxyfluorfen, (B) flumioxazin, (C) nicosulfuron, (D) mesotrione, (E) clethodim and (F) metsulfuron-methyl.

\section{LITERATURE CITED}

ASSIS, A. M. et al.Cultivo de orquídea em substratos à base de casca de café. Bragantia, v. 70, n. 3, p. 544-549, 2010.

FREITAS, F. C. L. et al. Controle químico de Brilhantina (Pilea mcrophylla) no cultivo de orquídeas. Planta Daninha, v. 25, n. 3, p. 589-593, 2007a.

FREITAS, F. C. L. et al. Controle de plantas daninhas na produção de mudas de plantas ornamentais. Planta Daninha, v. 25 , n. 3, p. 595-601, 2007 b.
JUNG, S. Level of protoporphyrinogen oxidase activity tightly correlates with photodynamic and defense responses in oxyfluorfen-treated transgenic rice. J. Pestic. Sci., v. 36, n. 1, p. 16-21, 2011.

JURSÍK, M. et al. Efficacy and selectivity of post-emergent application of flumioxazin and oxyfluorfen in sunflower. Plant Soil Environ., v. 57, n. 11, p. 532-539, 2011.

LORENZI, H.; SOUZA, H. M. Plantas ornamentais no Brasil: arbustivas, herbáceas e trepadeiras. 4.ed. Nova Odessa: Instituto Plantarum, 2008. 1120 p. 
MACIEL, C. D. G. et al. Seletividade de coroa-de-cristo (Euphorbia splendens) a diferentes classes de herbicidas para manejo de plantas daninhas em jardinagem. R. Bras. Hortic.

Ornam., v. 11, n. 2, p. 132-140, 2005.

PAULA, C. C.; SILVA, H. M. P. Cultivo prático de orquídeas. 3.ed. Viçosa, MG: Universidade Federal de Viçosa, 2006. 106 p.

PIVETTA, K. F. L. et al. Seletividade de sálvia (Salvia splendens) ao herbicida oxyfluorfen veiculado à palha de arroz. Planta Daninha, v. 26, n. 3, p. 645-655, 2008.
RODRIGUES, I. M. C. et al. Ocorrencia de plantas daninhas no cultivo de bromélias. Planta Daninha, v. 25, n. 4, p. $727-733,2007$.

SOCIEDADE BRASILEIRA DA CIÊNCIA DAS PLANTAS DANINHAS - SBCPD. Procedimentos para instalação, avaliação e análise de experimentos com herbicidas. Londrina: 1995.

SUZUKI, R. M. et al. Germinação e crescimento in vitro de Cattleya bicolor Lindley (Orchidaceae). Hoehnea, v. 37, n. 4, p. 731-742, 2010. 